\title{
Sustainable Ecotourism Management in Kenya
}

\begin{abstract}
The study of ecotourism impacts and their management offers many opportunities to reflect on the importance of sustainability and the possibilities of implementing approaches which move us in a new direction. Sustainability, then, is about the struggle for diversity in all its dimensions. The concern for biodiversity, in its broadest sense, encompasses not only threatened flora and fauna, but also the survivability of these human communities, as stewards of the natural environment and as producers. The research which adopts both quantitative and qualitative approaches, reports on the few attempts to identify ecotourism impacts and their management from the perspectives of all the stakeholders concerned which includes the visitors, tour operators, accommodation outlets, local community and Park and Reserve Management. The findings of this research therefore have implications for conservation management from the ecotourism point of view as well as an enhanced sustainable community development in Amboseli National Park and Masai Mara National Reserve.
\end{abstract}

*Roselyne N. Okech and **Urmilla Bob

Key Words: Amboseli, Ecotourism, Management, Masai Mara, Sustainable

\section{Introduction}

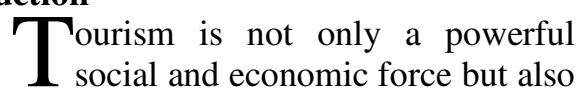
a factor in the physical environment as well. It has the power to enhance the environment, provide funds for conservation, preserve culture and history, to set sustainable use limits, and to protect natural attractions. It also has the power to contribute towards negative, social, economic and environmental impacts, especially in the host countries. Khan (2003) and Eagles (1995) state that within the tourism industry worldwide, ecotourism is one of the fastest growing sectors and has received considerable attention both in literature and the international marketplace. A frequently cited definition of ecotourism originated with The International Ecotourism Society (TIES) which states that ecotourism is responsible travel to natural areas which conserve the environment and sustains the well-being of local people (Ecotourism Society, 2000).

According to Sindiga (1999), ecotourism has generated great interest from governments, tourism enterprises, tourists, conservation groups and other stakeholders in the industry. Cater (1994) observed that one of the reasons for this interest is the availability of pristine natural environments, especially in Africa. These natural areas are attracting increasing numbers of visitors. Second, ecotourism emphasizes small-scale, locallyowned infrastructure in contradistinction with the expensive infrastructure associated with mass tourism. Ecotourism potentially provides a sustainable approach to development. The benefits of ecotourism include an enhanced appreciation of natural environments, both in terms of their intrinsic and economic worth for protection and conservation; the educational value of exposing visitors and locals to nature and conservation; and the potential of ecotourism to motivate the designation of additional natural areas for conservation and protection. Conversely, pressures originating from inappropriately managed infrastructure and visitor activities can adversely impact the receiving environment. Negative impacts on terrestrial ecosystems include destruction of plant and wildlife habitats; soil and dune erosion; soil compaction; disruption of soil stability; alteration of geological regimes; disruption of nutrient cycles; and reduction in biodiversity (Chin et al., 2000).

Literature reveals that despite calls by several authors such as Ap (1992) and Gee and Fayos-Sola (1997), few studies exist which examine different stakeholder perceptions within a given area, many studies tend to focus on one stakeholder group. In order to involve all stakeholders in the planning and management of ecotourism, an understanding of their perceptions is necessary. Gee and Fayos-Sola (1997) recognise this need, arguing that impacts can be perceived differently by different community members as well as interested and affected parties and that ecotourism can inevitably cause host-guest conflict. Without this context, effective and relevant management plans cannot be implemented, thus hindering the goal of meeting subjective beliefs or perceptions and ultimately achieving sustainable ecotourism. Kenya's tourism development is based on a number of objectives specified in the country's

*Department of Tourism Studies, Sir Wilfred Grenfell College, Memorial University of Newfoundland Canada Rnokech@yahoo.com

**Department Of Geography \& Environmental Studies (Westville Campus), University Of Kwazulu-Natal South Africa 
national development plans. Although the objectives spell out the desired economic outcomes of tourism development and the preservation of biodiversity aimed at making it sustainable, they in themselves do not meet the goals of planning (Sindiga, 1999). The issues facing Kenya's tourism industry that needs urgent attention can be linked to the following aspects as identified by Irandu (2003), Okech (2003) and Sindiga (1999):

- Breakdown of the physical infrastructure;

- Environmental degradation of natural resources, especially in the protected areas;

- A narrow tourism product and source market for tourists;

- Socio-cultural change and the uneven distribution of benefits, especially to local communities;

- Low foreign exchange earnings per capita and low retention rates;

- Mass tourism, foreign ownership and management of tourism enterprises;

- A small domestic and regional tourism base; and

- Political violence associated with the democratization process

\section{Stakeholder analysis}

Sautter and Leisen (1999) state that in order to implement stakeholder management, the tourism researcher must have a full appreciation of all the persons or groups who have interests in the planning process, delivery and/ or outcomes of the tourism service. Where stakeholder theory has been described as a planning and management tool, it is evident that stakeholder management and increased community participation in tourism has been discussed, particularly in relation to sustainable tourism (Baum, 1994; Butler, 1999; Getz and Jamal, 1994; Simmons, 1994; Yuksel et al., 1999). Consequently, stakeholder identification and involvement has-been recognised as a key step towards achieving partnerships and collaboration within tourism (Bramwell and Lane, 1999; Jamal and Getz, 1995; Selin 1999). Therefore, stakeholder analysis, as illustrated by Hardy and Beeton (2001) seems a logical method of identifying the multiple subjective opinions of those with a stake in tourism; and for planning it in a way to avoid any costs associated with poor planning and management and the resultant conflicts.

Grimble and Wellard (1997) argue that the advantage of stakeholder analysis is that it provides a methodology and a conceptual framework for a better understanding of environmental and developmental problems and interaction through comparative analysis of the different perspectives and stakeholder interests at different levels. Jones (1995) submits that from a managerial perspective, the stakeholder theory posits that the various groups can and should have a direct influence on managerial decision-making. As such, effective management demands synchronous attention to the genuine interests of all appropriate stakeholders (Donaldson and Preston, 1995).

\section{Study Area}

Kenya has one of the most successful wildlife tourist industries in the developing world. In order to sustain ecotourism in Kenya, it is essential to understand the potential effects of the expanding ecotourism sector on natural and social environments, so as to identify management priorities for present and potential ecotourist destinations. The research was conducted in two areas namely Amboseli National Park and Masai Mara National Reserve in Kenya (see Figure 1) Opened in 1948, Amboseli is the next most popular Park after Masai Mara, mainly because of the spectacular backdrop of Africa's highest peak, Mount Kilimanjaro. At 392 sq.km, it was first gazetted as a national park in 1974. It offers fifty-three species of herbivores and carnivores - the most conspicuous being its elephant population, whose individuals are known by name, age and sex. There are three hundred and eighty seven species of birds, reptiles and amphibians recorded in the Park. The Masai Mara at 320 sq.km is the most popular game reserve in Kenya. The reserve, gazetted in 1961 , is located west of the rift valley and is a natural extension of the Serengeti plains in Tanzania. From July to October, Masai Mara is at its peak, with seasonal visitors populating the vast grasslands. A usual activity during the stay at Mara is a visit to one of the numerous Masai villages or manyattas. The Amboseli National Park and the Masai Mara National Reserve in Kenya were chosen for a number of reasons. Firstly, because of the long-standing popularity of national game parks and reserves in Africa which has given rise to many studies documenting the impact of tourism on wildlife. Secondly, Muthee (1992) observed that the Amboseli National Park and the Masai Mara National Reserve have experienced severe problems of tourist congestion, animal harassment by tourist vehicles and overexploitation of resources. 



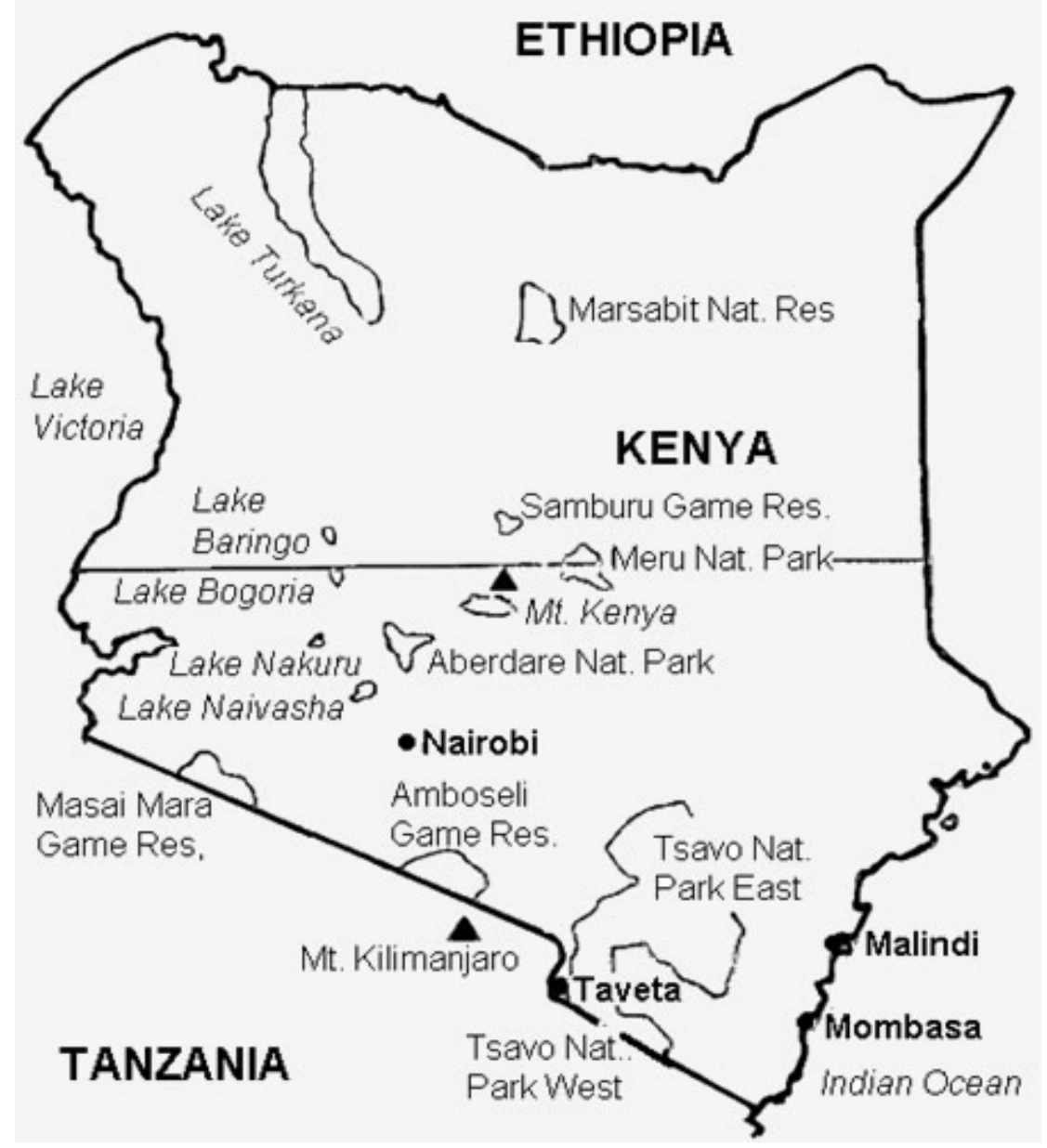

Source: Madukha Safaris

\section{Methodology}

Survey questionnaires with key stakeholder groups (visitors, tour operators, local communities, accommodation personnel and managers) were conducted at Mara and Amboseli. In total, two hundred visitors (one hundred in each study area) using convenient sampling were chosen. A questionnaire survey was conducted with ten tour operators in Amboseli and Mara. It is the assumption of the study that the same operator was likely to operate in both the areas. Therefore, the tour operators were purposively selected using a list obtained from the accommodation outlets. A total of ten respondents (five in each study area) from the different accommodation facilities within Amboseli and Mara were selected using convenient sampling. One hundred households each from communities adjacent to Amboseli and Mara were interviewed by adopting a snowball sampling technique. Finally, two respondents (one from each study site) from the management of the Park and Reserve were chosen purposively to be key informants on behalf of the overall management of the Amboseli and Mara.

\section{Results and Discussion}

This section presents findings pertaining to sustainable ecotourism management as ascertained from the following stakeholders: visitors, tour operators, and accommodation personnel, local communities adjacent to Mara and Amboseli as well as the management of both Mara and Amboseli.

Visitors

Visitor attitudes to potential management actions can assist in predicting the consequences of specific actions on the ecotourist experience, and thus result in management actions that take into account both visitor satisfaction and ecological-well being. All management strategies gained substantial support including 'direct' regulatory actions such as limiting forest use and limiting the number of people, as well as 'indirect' actions such as education. Amboseli and Mara respondents provided less support and more opposition to providing more visitor 
facilities (37\% in Amboseli and 36\% in Mara) and providing more staff $(34 \%$ in Amboseli and $41 \%$ in Mara) than any other suggested management strategy (see Table 1).

Table 2 revealed the Visitor's perceptions of observed and potential impacts based on the premise that conditions of importance to visitors themselves are the best indicators of factors likely to adversely affect visitor experiences. Assessing and monitoring the conditions and situations of these visitorconcentrated sites is essential for both the protection of recreational resources and the provision of quality recreational experiences.Impacts most frequently observed by visitors included soil erosion at walk trails, too many people and vegetation damage. A number of respondents also commented on other impacts that included provocation of wildlife, bad roads and lack of enforcement of Parks' regulations. For almost all the impacts, a greater number of respondents expressed concern about the potential impact than observed impact, especially too many people signified by 59\% of visitors in Amboseli and $60 \%$ of visitors in Mara followed by vegetation damage (56\% of respondents in Amboseli and $54 \%$ in Mara).

When asked to indicate how they felt about environmental impacts in Amboseli and Mara (Table 3), the respondents emphasized biophysical rather than social conditions. One reason why many visitors identify biophysical impacts as problematic is that they are visually prominent. Further, greater visitor concern with biophysical over social conditions possibly reflects the view that although visitor use results in impacts, present levels of use are not in themselves reducing the quality of the visitor experience (Chin et al., 2000). These results regarding visitor perceptions of the impacts of tourist use can be used to identify potential indicators for monitoring environmental conditions in Amboseli and Mara. This approach is based on the premise that the best indicators are the conditions of most importance to visitors.

\section{Tour operators}

It is worth noting that $60 \%$ of operators in Mara have been in business for more than 15 years compared to only $30 \%$ in Amboseli. This does not imply that the length of operations is the sole contributor to the negative impacts of ecotourism in the both Mara and Amboseli since the tour operators' clients had other interests as well.
But it is certainly a factor which management could use to ensure that the long serving operators to the study areas are indeed environmentally conscious and adhere to the social, economic and environmental laws. The tour operators, however, took measures in environmental care by avoiding waste generation through burning of waste, providing garbage bins and waste disposable bags in vehicles, burying trash, educating both staff and visitors on proper waste disposal while on game drives, encouraging the use of re-usable/ recycle packaging and bio-degradable materials as well as giving the visitors a copy of conservation notes. Tour operators to Amboseli paid locals to perform cultural dances and entertain visitors, the visitors are also encouraged to pay tips, establish organisations that will look into the welfare of the community, support communities through visits to their manyattas, purchase artifacts and souvenirs, donate books to locals and contribute to ongoing projects in the community.

Tour operators also contributed to education and ecotourism management through staff training and creating awareness; participation in activities by the Ministry of Tourism; supported ecotourism initiatives; as well as reducing vegetation damage by making fewer trips to the Reserve and Park. Observational data suggest that most drivers are generally responsive to clients' questions but do not volunteer much information or interpretation. Training programmes for drivers and interpretive information could therefore become a significant tool in visitor management in Mara and Amboseli.

\section{Accommodation managers}

The results show that $60 \%$ of the accommodation outlets in Amboseli and 40\% in Mara belonged to conservation organisations. All the outlets in Mara and 80\% in Amboseli had a stated code of ethics for their staff and visitors. The personnel also enforced guidelines for field behaviour for their staff and visitors especially in regard to environmental rules and for behaviour around sensitive habitat or wildlife through advice, training, Ecotourism Society of Kenya (ESOK) code given to the guests, briefings, environmental awareness exercises, signs and video shows. The accommodation managers were also asked their response towards the number of visitors and vehicles to Amboseli and Mara. In Amboseli, $60 \%$ of the 
accommodation outlets felt that the number is very encouraging bearing in mind the number of beds available at Amboseli, the traffic of both visitors and vehicles is within acceptable levels and should be increased by an average of $30 \%$.

Twenty percent of the respondents stated that that the numbers are not the problem, the problem is the location of camps/ lodges that are poorly planned which leads to vehicles concentrating in one area. Furthermore, some drivers are irresponsible or untrained and game viewing circuits and routes are not well planned. A further $20 \%$ of the accommodation outlet respondents felt that the Park is threatened by too many lodges and tourist buses, which drive off-road, damaging the fragile plant life in the Park. The respondents were also asked to identify some of the negative and positive effects of ecotourism they had observed in Amboseli and Mara.

With regard to developmental concerns, the respondents identified the following changes that have occurred in Amboseli and Mara over the last five to ten years: more accommodation outlets have sprung up, repairs on airstrip, roads have slightly improved, there are schools for the local communities, and training of game rangers to patrol the camps and Parks. They, however, were interested in seeing some changes including improved toilet facilities for visitors arriving by airstrip, widening some part of the road by the swamp to allow vehicles to stop and watch birds while other vehicles can pass, fencing of more areas to promote growth of trees, more environmental awareness participation, the reduction of tented camps, signage to be improved, more schools and facilities for the locals, reduction of balloon safaris, control of grazing cattle in the Parks, and management coming up with projects to help the livelihoods of the locals.

These results show that indeed there is concern regarding ecotourism impacts and how they are managed. Collective responsibility is definitely the key to successful biodiversity conservation and sustainable development. These results show that there is a willingness to promote positive environmental protection among the accommodation managers. In order to maintain and build up a high-quality natural environment, investments in environmental protection, which may be insufficient at present, should be increased through government funding, readjustment of current policies, and establishment of foundations and donation mechanisms to meet the goal of ecotourism management in the Amboseli and Mara. Regular meetings with the community organizations and the general community allows members of the community to voice their opinions concerning negative consequences of ecotourism and to indicate strategies that they believe should be undertaken to manage these impacts.

\section{Local communities adjacent to Mara and Amboseli}

Why should villagers respect a protected area boundary that cuts off their access to resources? Why should a logging community support the protection of an endangered species habitat? What is the appeal of "ecotourism" to a community if the profits from the venture go elsewhere? These questions suggest that access to resources and accrued revenues are important considerations for local communities. Over half of the respondents indicated that two or more family members work in the tourism industry. Nearly half indicated that their family had received direct economic benefits from tourism, either money from camping concessions or from fees paid to visit manyattas, and from the sale of jewellery (handicrafts). However, about half the respondents indicated the benefits were not adequate to offset the negative impacts of tourism and wildlife in their areas. Part of community development is dependent on the access to natural resources.

The results in Table 4 reveal how the communities benefit from ecotourism. The respondents, however, generally did not benefit from training (67\% in Mara and $70 \%$ in Amboseli), natural resource management (70\% in Mara and 63\% in Amboseli) and decisionmaking (83\% in Mara and $73 \%$ in Amboseli). It is evident that they would like to benefit in terms of medical facilities, better ways of communication, transport, better infrastructure, more training, as well as having access to sufficient amounts of revenue and grazing land. Indeed, people living in areas of high biodiversity value may have more convincing reasons to over-exploit resources than to conserve them. The benefits of job opportunities were high in Mara (73\%) and relatively low (40\%) in Amboseli. Many communities in Masailand simply have no economic incentives to conserve biodiversity. In these communities, the key to successful conservation is making sure that they share the 
benefits fairly and do not shoulder a disproportionate share of the costs.

In communities where economic incentives do exist, local authorities and communities need to regulate the use of biodiversity within wider resource management plans and to apply technical skills to manage and conserve biological resources. Important here, as noted by Roque (1992), are legally recognized and enforceable rights to land, which give the communities both an economic incentive and a legal basis for stewardship. If people are deprived of access to resources because of the development of ecotourism, and yet do not receive any benefits from ecotourism, it is unlikely that they will have support for conservation of the natural resources upon which ecotourism is based. Policies should be applied in such a way as to help raise the standards of living of the populations of the regions visited and meet their needs. Only 15\% in Mara and 26\% in Amboseli participated in the operation and management of the Reserve and Park through employment at the office and lodges as well as game rangers.

The communities who did not participate $(85 \%$ in Mara and $74 \%$ in Amboseli) suggested that they would like to be involved through the following ways: incorporating community with wildlife related organizations; getting some percentage from tourism in the Reserve and Park; seminars and internal training; employment; providing services which are able to benefit the whole society; decision-making in funded projects as well being given opportunities to participate in ecotourism operations. The interaction of the communities with the management and staff of Mara and Amboseli is either very good or good (73\% in Mara and 67\% in Amboseli). The reasons cited include selling of curios, being allowed to work independently, education opportunities, there is cooperation, fencing has been done to protect the destruction of vegetation and consideration of transport for the locals to town.

A further $17 \%$ of community members in Mara and $13 \%$ in Amboseli cited poor relations due to the fact that they are not involved in any decision-making and management of the Park/ Reserve, discrimination in employment, no benefits when they or their livestock are injured or even killed by wild animals, poor management of the electric fences and services are not distributed equally for the benefit of all the community members. Communities should therefore be involved in monitoring and evaluating projects over time. Their voices and their concerns should guide the development of any ecotourism project from the feasibility stage through to its implementation. In programmes encouraging community involvement in the management of natural resources, and ecotourism in particular, it is typically expected that a representative body will be formed to convey community interests and act on behalf of the community.

The community members also mentioned some problems that they were experiencing as a result of residing adjacent to Mara and Amboseli. These included loss of human life and livestock being killed by wild animals, destruction of crops by wild animals, overgrazing problems, lack of enough grass for the animals, diseases from wildlife to the livestock, environmental degradation by elephants, game rangers patrolling the Parks to chase livestock, and language problems. In view of the concerns mentioned, the community and management are trying to resolve the stated problems by enhancing more protection for human lives and livestock, formation of conflict resolution committees, home guards as well as compensation for losses.

\section{Conclusion}

Ecotourism is undoubtedly a key feature in Kenya's economy. However, this study reveals that the ecotourism sector faces several challenges which include the need to respond to local community development and aspirations, meeting visitor's varied expectations, improving management and planning efforts as well as developing effective and efficient infrastructure and services. According to Gakahu (1992), Kenya has a policy that emphasizes those habitats and wildlife populations are to be maintained in a reasonably 'natural' state while catering for economically important activities. This is important for the tourist industry because the naturalness of amenities is what attracts tourists and is what they pay for. Appropriate planning and management is necessary to redress past mistakes and ensure the future welfare of ecotourism. One cannot rule out the possibility that at some point, conservation and economic exploitation, through ecotourism, might become incompatible unless appropriate mechanisms of reconciling them are worked out. 
Today, the ecological integrity and attractiveness of the Amboseli and Mara conservation areas is being impaired by visitor use. In conclusion, immediate, short-term and long-term planning and management actions need to be taken in order to stop the current poor use and localized overuse of the Amboseli and Mara. The best use of visitor attitudes and use impacts outlined in this study could guide management. This study clearly demonstrates that simply calculating visitor figures is insufficient for management, planning and monitoring responses. If the management cannot deal with the identified problems, then there is need to establish visitor capacity. Visitor impact management programmes therefore can minimise visitor impacts before costly restoration and rehabilitation programs become necessary.

From the data description and analysis, it can be concluded that ecotourism impacts and their management in both Amboseli National Park and Masai Mara can be managed and be sustainable if the views of all stakeholders who participated in the study are taken into consideration. The local communities must have access to resources of tourism in the region. All the stakeholders have agreed to several changes that are necessary for sustainability in both the study areas which included repairs of infrastructure, education and interpretation, more community benefits, as well as better biodiversity conservation. Drastic changes must therefore take place if ecotourism initiatives are to satisfy everyone involved. It is evident that the respondents in the study are willing to make certain behavioural changes in view of the social, economic and environmental impacts that may accrue in the future. In terms of similarities, the analysis revealed the following:

- Visitors, locals, operators and regulators all had concerns about the impacts of ecotourism, although locals gave greater emphasis to the economic impacts than operators and regulators. Some stakeholders within each of these stakeholder groups also expressed concern over the quality of the ecotourism product, although the predominant concern regarding this issue was from visitors.

- Operators, regulators and some visitors had similar concerns with what they perceived to be high numbers of visitors and vehicles in the regions. Locals and operators had similar perceptions of what visitors expected in Amboseli and Masai Mara as both stakeholder groups suggested that visitors sought wildlife experience whilst in the area. The results reveal that local people, operators and regulators differed in what they perceived to be the primary concerns about ecotourism in Amboseli National Park and Masai Mara National Reserve. Visitors were concerned with aspects that would make their experience better, locals were concerned with the effects of ecotourism on the local community, operators were primarily concerned with issues related to the ecotourism product such as visitor satisfaction and regulators' primary concern was the infrastructure as well as laws and policies governing ecotourism.

This study highlights the need for strict management of ecotourism projects in their planning and implementation to ensure that ecotourism has minimal negative sociocultural as well as environmental impacts. It also emphasizes the need for managers of ecotourism projects to develop regional strategies and to use an integrated effort in directing and controlling socio-cultural and environmental impacts. It concluded that, collaboration among key players is a fundamental ingredient in sustainable development efforts. More specifically, ecotourism planners should proactively consider the strategic orientations of all groups affected by the venture before proceeding with development efforts. 



\section{References}

Ap, J. (1992) Residents' Perceptions on Tourism Impacts, Annals of Tourism Research 19 (4):665-690.

Baum, T. (1994) The Development and Implementation of National Tourism Policies, Tourism Management 15 (3): 185-192.

Bramell, B. and Lane, B. (eds.) (1999) Tourism Collaboration and Partnerships. Politics, Practice and Sustainability Clevedon: Channel View.

Butler, R.W. (1999) Sustainable Tourism: A State-of-the-Art Review, Tourism Geographies $1(1): 7-25$.

Cater, E. (1994) Ecotourism in the Third World - Problems and Prospects for Sustainability, In: E. Cater and G. Lowman (eds.) Ecotourism: A Sustainable Option? New York: John Wiley and Sons.

Chin, C.L.M., Moore, S.A., Wallington, T.J. and Dowling, R.K. (2000) Ecotourism in Bako National Park, Borneo: Visitors' Perspectives on Environmental Impacts and their Management, Journal of Sustainable Tourism 8 (1): 20-35.

Donaldson, T. and Preston, L.E. (1995) The Stakeholder Theory of the Corporation: Concepts, Evidence and Implications, Academy of Management Review 20: 65-91.

Eagles, P.F.J. (1995) Understanding the Market for Sustainable Tourism, In: S.F. McCool and A.E. Watson (eds.) Linking Tourism, the Environment and Sustainability, Topical Volume of Compiled Papers from a Special Session of the Annual Meeting of the National Recreation and Park Association, 1994 October 12-14 Minneapolis, Report INTGTR-323. Ogden, UT: US.

Ecotourism Society (2000) Ecotourism Statistical Fact Sheet, Alexandria, V.A: Ecotourism Society.

Gakahu, C.G. (1992) Participation of Local Communities in Ecotourism: Rights, Roles and Socioeconomic Benefits, In: C.G. Gakahu and B.E. Goode (eds.) Ecotourism and Sustainable Development in Kenya, Wildlife Conservation International.

Gee, C.Y. and Fayos-Sola, E. (1997) International Tourism: A Global Perspective, Madrid: World Tourism Organisation.

Getz, D. and Jamal, T.B. (1994) The Environment-Community Symbiosis: A Case for Collaborative Tourism Planning, Journal of Sustainable Tourism 2 (3): 152-173.
Grimble, R. and Wellard, K. (1997) Stakeholder Methodologies in Natural Resource Management: A Review of Principles, Contexts, Experiences and Opportunities, Agricultural Systems 55 (2): 173-193.

Hardy, A.L. and Beeton, R.J.S. (2001) Sustainable Tourism or Maintainable Tourism: Managing Resources for More Than Average Outcomes, Journal of Sustainable Tourism 9 (3): 168-192.

Irandu, E.M. (2003) Wildlife Tourism and Local Communities in Kenya, Paper Presented at ATLAS-Africa Conference, held in Arusha, Tanzania, February 20-22.

Jamal, T.B. and Getz, D. (1995) Collaboration Theory and Community Tourism Planning. Annals of Tourism Research 22, 186-204.

Jones, T.M. (1995) Instrumental Stakeholder Theory: A Synthesis of Ethics and Economic, Academy of Management Review 20 (2): 404437.

Khan, M. (2003) ECOSERV Ecotourists' Quality Expectations, Annals of Tourism Research 30 (1): 109-124.

Okech, R.N. (2003) Wildlife Tourism and Community Conflicts: Future Needs and Perspectives, Paper Presented at ATLASAfrica Conference held in Arusha, Tanzania, February 20-22.

Roque, C. (1992) Creating Conditions and Incentives for Local Biodiversity Conservation, In: Global Biodiversity Strategy, Guidelines for Action to Save, Study, and Use Earth's Biotic Wealth Sustainably and Equitably, Published by WRI, IUCN and UNEP in Consultation with FAO and UNSESCO.

Sautter, E.T. and Leisen, B. (1999) Managing Stakeholders: A Tourism Planning Model" Annals of Tourism Research 26 (2): 312-328.

Selin, S. (1999) Developing a Typology of Sustainable Tourism Partnerships, Journal of Sustainable Tourism 7 (3 and 4): 260-273.

Simmons, D.G. (1994) Community Participation in Tourism Planning, Tourism Management 15(2): 98-108.

Sindiga, I. (1999) Tourism and African Development: Change and Challenge of Tourism in Kenya, African Studies Centre Research Series.

Yuksel, F., Brawmwell, B. and Yuksel, A. (1999) Stakeholder Interviews and Tourism Planning at Pamukkale, Turkey, Tourism Management 20 (3): 351-360. 
Table 1: Potential Management Strategies (in \%)

\begin{tabular}{|l|c|c|c|c|}
\hline \multirow{2}{*}{ STRATEGY } & \multicolumn{2}{|c|}{ AMBOSELI (n=100) } & \multicolumn{2}{c|}{ MARA (n=100) } \\
\cline { 2 - 5 } & Agree & Disagree & Agree & Disagree \\
\hline Educate visitors more about conservation & 73 & 3 & 89 & 1 \\
\hline Provide more maps and signs & 53 & 10 & 68 & 13 \\
\hline Limit the overall number of visitors & 53 & 12 & 64 & 12 \\
\hline Limit the use of forest area & 62 & 8 & 61 & 12 \\
\hline Limit length of stay & 39 & 12 & 38 & 27 \\
\hline Provide more visitor facilities & 30 & 37 & 26 & 36 \\
\hline Provide more staff & 30 & 34 & 16 & 41 \\
\hline Limit number of vehicles & 66 & 8 & 67 & 13 \\
\hline
\end{tabular}

Table 2: Observed and Potential Impacts (in \%)

\begin{tabular}{|l|c|c|c|c|}
\hline \multirow{2}{*}{ IMPACTS } & \multicolumn{2}{|c|}{ Observed $(\mathbf{n = 1 0 0})$} & \multicolumn{2}{c|}{ Potential (n=100) } \\
\cline { 2 - 5 } & Amboseli & Mara & Amboseli & Mara \\
\hline Soil erosion at walk trails & 47 & 27 & 76 & 65 \\
\hline Smelly or discolored water & 12 & 29 & 21 & 38 \\
\hline Litter & 15 & 28 & 38 & 38 \\
\hline Vegetation damage & 57 & 29 & 56 & 54 \\
\hline Too many people & 29 & 54 & 59 & 60 \\
\hline Health/condition of wildlife & - & - & 47 & 50 \\
\hline
\end{tabular}

Table 3: Environmental Conditions (in \%)

\begin{tabular}{|l|c|c|c|c|}
\hline \multirow{2}{*}{ CONDITION } & AMBOSELI (n=100) & \multicolumn{2}{c|}{ MARA (n=100) } \\
\cline { 2 - 5 } & $\begin{array}{c}\text { Serious/slight } \\
\text { problem }\end{array}$ & $\begin{array}{c}\text { Not a } \\
\text { problem }\end{array}$ & $\begin{array}{c}\text { Serious/slight } \\
\text { problem }\end{array}$ & $\begin{array}{c}\text { Not a } \\
\text { problem }\end{array}$ \\
\hline Number of man-made structures & 33 & 67 & 40 & 60 \\
\hline Size of groups encountered & 43 & 57 & 62 & 38 \\
\hline Number of people encountered & 45 & 55 & 65 & 35 \\
\hline Litter around the park & 28 & 72 & 53 & 47 \\
\hline Litter around accommodation & 27 & 73 & 43 & 57 \\
\hline Damage to natural vegetation & 63 & 37 & 68 & 32 \\
\hline Erosion along walk trails & 58 & 42 & 60 & 40 \\
\hline Health/condition of wildlife & 39 & 61 & 54 & 46 \\
\hline
\end{tabular}

Table 4: Ecotourism Benefits (in \%)

\begin{tabular}{|l|c|c|c|c|}
\hline \multirow{2}{*}{ BENEFITS } & \multicolumn{2}{|l|}{ MARA $(\mathbf{n}=\mathbf{3 0})$} & \multicolumn{2}{c|}{ AMBOSELI (n=30) } \\
\cline { 2 - 5 } & YES & NO & YES & NO \\
\hline Education & 50 & 50 & 53 & 47 \\
\hline Job opportunities & 73 & 27 & 40 & 60 \\
\hline Training programme & 33 & 67 & 30 & 70 \\
\hline Natural resource management & 30 & 70 & 37 & 63 \\
\hline Decision-making & 17 & 83 & 27 & 73 \\
\hline Tourism/ecotourism & 73 & 27 & 67 & 33 \\
\hline
\end{tabular}

